\title{
A PROHIBITION ON INCENTIVE TO REDEEM IN CAPITAL REGULATION
}

\author{
László Seregdi
}

\begin{abstract}
Pursuant to the Capital Requirement Regulation (CRR) of the EU, a capital instrument has to fulfil several conditions so that a credit institution can count it as a component in its own funds. Most of the conditions listed in the CRR are clear and well-defined, therefore their observance is easy to control. However, some conditions are not so unambiguous, e.g. the prohibition on incentive to redeem is particularly difficult to interpret. The condition above also appears among the requirements of Additional Tier 1 capital, Tier 2 capital and eligible liabilities. This study aims to present the economic logic of the prohibition on incentive to redeem, how the fulfilment of this condition can be checked and how regulatory authorities interpreted the fulfilment of the conditions regarding the prohibition on incentive to redeem in specific cases.
\end{abstract}

JEL codes: $\mathrm{G}_{21}, \mathrm{~K}_{22}, \mathrm{~L} 51, \mathrm{~N}_{24}, \mathrm{O}_{16}$

Keywords: own funds, bank regulation, repurchase

\section{INTRODUCTION}

In addition to the excessive leverage in the banking system and the lack of appropriate liquidity buffers, the gradual deterioration of the volume and quality of own funds played an important role regarding the main reasons for the global financial crisis (BCBS, 2017). The Basel Committee contributed to this process, as well, as many of its guidelines resulted in the dilution of own funds (e.g. eligibility of hybrid capital items under lax conditions, acceptance of short-term subordinated loans as the fulfilment of the capital requirement for market risk). Therefore, based on its experience gained during the global financial crisis, the Basel Committee strove to take measures to improve the volume and quality of own funds.

1 László Seregdi, supervisory advisor at the Regulatory Department of the National Bank of Hungary. E-mail: seregdil@mnb.hu. 
The quantitative measures primarily aimed to tighten the existing capital requirement rules (e.g. the minimum level of the CET1 ratio: $4.5 \%$ ) and add new capital requirements (e.g. the introduction of capital buffer requirements).

The measures to improve the quality of capital focused on three main topics: the improvement of loss-absorbing capacity, the flexibility of payments and permanence. For example, in accordance with a measure to improve loss-absorbing capacity, owing to the structure of minimum capital requirements, banks had to increase the ratio of Common Equity Tier 1 within the own funds and carry out most deductions from Common Equity Tier 1. The flexibility of payment is ensured by the fact that no minimum dividend payment obligation can be related to a Common Equity Tier 1 instrument. The bank shall always make a decision on the rate of dividend, depending on its actual prudential situation and successfulness. In the framework of permanence, the Basel III guidelines recognise only Common Equity Tier 1 and Additional Tier 1 capital without maturity date.

In order to ensure permanence, in addition to the components mentioned above, the Basel III guidelines also included a further additional requirement, which was adopted by the European Union in the Capital Requirements Regulation (CRR $\left.{ }^{2}\right)$ later. This requirement was the prohibition on incentive to redeem related to the AT 1 - Additional Tier 1 capital and the T2 - Tier 2 capital. Due to the amendments to the CRR made in 2019, the same requirement appears in relation to eligible liabilities (MREL - Minimum Requirements of Own Funds and Eligible Liabilities), as well.

\section{CONNECTION BETWEEN THE CAPITAL REQUIREMENTS AND THE OWN FUNDS, THE IMPORTANCE OF AT1 AND T2 CAPITAL ITEMS}

The minimum capital requirements (Pillar 1) of credit institutions are set as a percentage of total risk exposure. Such requirements are complemented by the additional capital requirement (Pillar 2) determined by the supervisory authority, the MREL requirement determined by the resolution authority, the combined capital buffer requirement prescribed by the law or the macroprudential authority and the capital guidance set by the supervisory authority based on the results of stress tests. The credit institutions can fulfil the aforementioned requirements and expectations by CET 1 - Common Equity Tier 1, Additional Tier 1 capital, Tier

2 Regulation (EU) No 575/2013 of the European Parliament and of the Council of 26 June 2013 on prudential requirements for credit institutions and investment firms and amending Regulation (EU) No 648/2012 
2 capital and eligible liabilities, which can only be considered if they comply with the numerous criteria specified in the CRR and the relevant Commission Technical Standards. A considerable part of the capital requirements can be fulfilled only by Common Equity Tier 1, therefore the availability of the appropriate volume of CET 1 is essential for the prudent operation of a bank. At the same time, legislation also allows the involvement of further capital items. Basically, CET 1 equity instruments (e.g. common stock) and the reserves useable for covering losses (e.g. retained earnings, capital reserves) without restriction can be included in the CET 1. AT1 equity instruments are usually undated bonds which can be converted into CET 1 equity instruments in the event of a crisis or the arising loss may be written down directly from them. The T2 equity instruments usually include bonds the maturity of which exceeds five years and the buyer of the bond agrees to be the last preceding shareholders in priority in liquidation of the credit institution (subordinated liability). The eligible liabilities are loans taken out or bonds issued by the bank or deposits placed with the bank (except for deposits covered by deposit insurance) from which the loss may be written down in the event of a crisis.

Although the role of the AT1, T2 capital items and the MREL-eligible liabilities is not as important as that of the $\mathrm{CET} 1$, but several credit institutions use them on a complementary basis and they would not be able to fulfil the capital requirements without such items. Based on the above, it is important to examine whether these equity instruments and MREL-eligible liabilities ${ }^{3}$ comply with the provisions of the CRR on the prohibition on incentive to redeem, because, otherwise, the equity instruments cannot be included in the own funds and the given liability will not be MREL-eligible and this may endanger the prudent operation of the institution. According to a recent survey conducted by the European Banking Authority (EBA), in 2019, more than $45 \%$ of the banks interviewed were planning to raise additional MREL-eligible liabilities. More than $20 \%$ of the banks were planning to involve additional Tier 1 capital or Tier 2 capital (EBA, 2019).

The detailed relationship between the capital requirements and the own funds is illustrated by Figure 1.

3 Due to the amendments to the CRR2, as of 28 June 2021, MREL-eligible liabilities will not be allowed to contain any incentive to redeem component. 
Figure 1

Relationship between the capital requirements and the own funds instruments

\begin{tabular}{|l|}
\hline Capital guidance: Specified \\
by the supervisory authority \\
based on the results of stress \\
tests
\end{tabular}
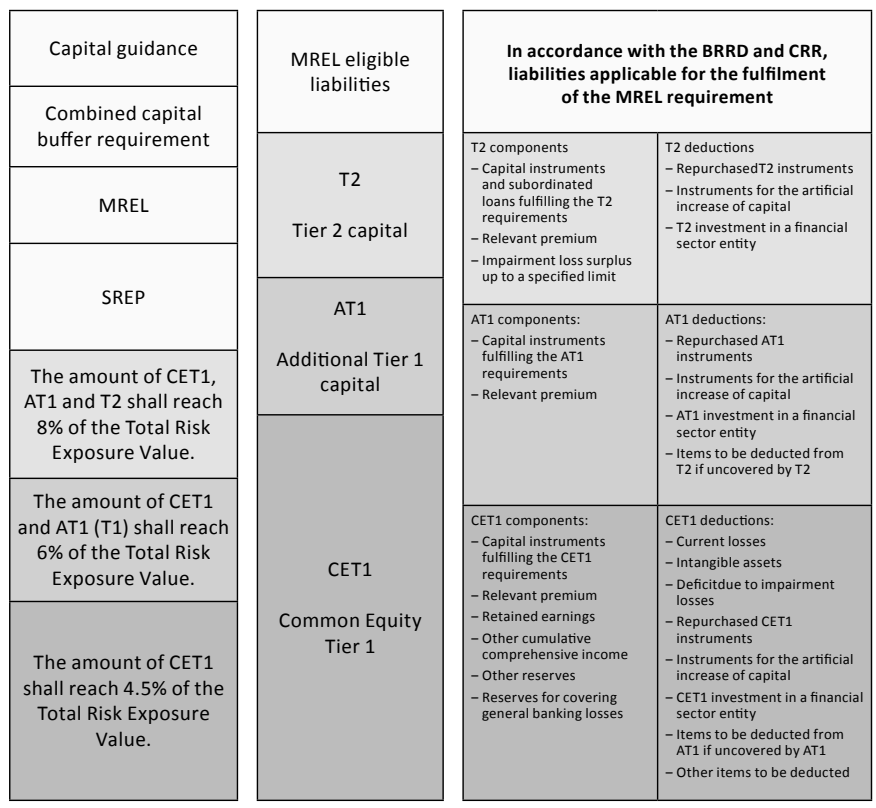

Source: own design

Since the global financial crisis, financial regulators have been striving to increase the role of CET1 in every country. As a result, the requirements set by the Basel Committee and the European Union have changed into this direction, as well. Examining the year-end data of the Member States of the EU from 2017, it is observable that there were 16 Member States in which the percentage of CET1 exceeded $90 \%$ within the total amount of own funds. The percentage of CET1 was the lowest in the Netherlands and the UK, but it still reached $76 \%$ and $72 \%$ in these Member States respectively. The percentage of Additional Tier 1 exceeded $5 \%$ only in six countries, from which it was the highest in the UK with $11.48 \%$. The role of Tier 2 capital was more significant, as its percentage within own funds exceeded $10 \%$ in 11 countries. In this respect, the leader was also the UK with $16.29 \%$. Figure 2 shows the percentage of capital items $\mathrm{CET}_{1}, \mathrm{AT}_{1}$ and $\mathrm{T}_{2}$ within the own funds in the individual EU Member States.

As the figure indicates, on the whole, Hungary is in an average position the percentage of CET1 within the total amount of own funds is $89.41 \%$, while the Additional Tier 1 capital with a percentage of $0.09 \%$ is negligible and the percentage of Tier 2 capital $(10.50 \%)$ is more significant. 
In the light of the above, on the one hand, regarding their rate, the AT1 and T2 capital items seem to be less important in the EU and in Hungary than CET1, on the other hand, they complement the CET1 capital items effectively, as they have to comply with less stringent requirements. At the same time, they are still suitable for covering the arising losses in the event of a crisis.

\section{Figure 2}

The role of CET1, AT1 and T2 in the own funds in the EU Member States at the end of 2017

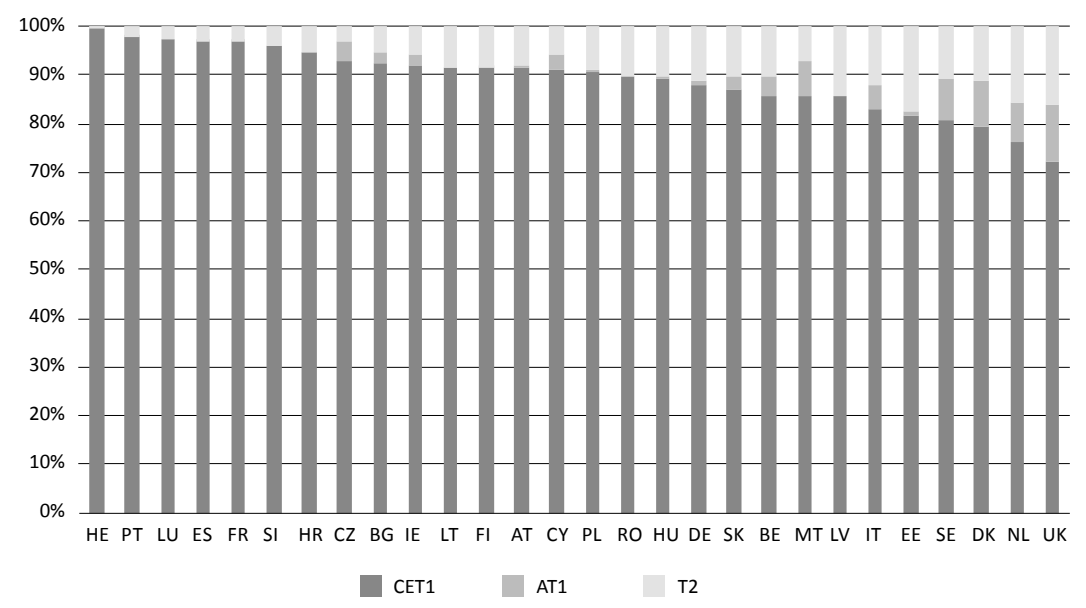

Source: EBA - Supervisory Disclosure

\section{PROHIBITION ON INCENTIVE TO REDEEM}

The CRR prohibits repurchase incentive under several names (reduction, call, redemption, reimbursement). For the sake of simplicity, hereinafter, we will uniformly use repurchase, as in an economic sense, the other names refer to more or less the same content, as well. The economic rationale behind the prohibition on incentive to redeem is that it infringes the requirement of permanence if, at the time of issue, the buyer of a given capital instrument received information based on which it may be assumed with reason that the originally undated or long-term capital instrument (e.g. bond) will actually have shorter maturity. This situation occurs if the conditions of the issue of the capital instrument encourage the issuer to repurchase the given instrument after a while. In possession of such information, the investor does not plan to buy the capital instrument for a longer term, but only rather until the date when it is repurchased by the institution. In this 
case, neither can the issuing institution expect the long-term availability of the capital instrument.

A classic example for incentive to redeem is step-up, i.e. the gradual increase of the yield to be paid on the capital instrument. For example, if the yield of a subordinated loan with a maturity of 10 years starts increasing gradually for 5 years after the date of issue accompanied with a call option in the framework of which the institution has the right to repurchase the security belongs to the bond, the buyer of the bond may reasonably assume that the institution will have no choice but to repurchase the bond sooner or later, as it will become a more and more expensive source of funding for the institution. Applying a maturity of ten years instead of five years might be more advantageous for the issuer, as the total amount of the subordinated loan with a maturity of ten years can be offset in the own funds for five years after the date of issue, while in the case of a subordinated loan with a maturity of less than five years, the amount that can be counted in the own funds is continuously decreasing.

The repurchase of the capital instrument is disadvantageous for the institution, because it reduces its own funds and there is a risk that the institution will not be able to fulfil the prudential requirements related to the own funds (e.g. riskweighted exposure ratio, leverage ratio and large exposure).

The continuous increase in the interest payable on the instrument can also be considered as a continuous fine for the issuer, because, as a result, the fund from the instrument will be increasingly expensive. In view of the above, earlier, the participants used to interpret a call-back option related to the increase in the interest as the actual maturity of the bond, as the call-back was bound to happen owing to the rising interest anyway. The lack of call-back used to be regarded as a fiduciary risk, as it suggested the investors that the issuer had funding problems (Corcuera et al., 2014).

Based on the above, the CRR prohibits not only repurchase incentives belonging to own funds items, but it also lays down that the call-back, redemption, repayment or repurchase of Additional Tier 1 capital instruments and the T2 capital instruments prior to their contractual maturity date shall be subject to strict conditions and prior supervisory approval.

In the example above, repurchase incentive is obvious, therefore such a capital instrument cannot be counted in the own funds, as it fails to fulfil the requirement of permanence. However, based on practical experience, in many cases, it is not so easy to decide whether repurchase incentive occurs or not. Consequently, in our study, after a short summary of the regulatory background, we describe practical examples where more thorough analysis is needed to answer the question. 


\section{REGULATORY BACKGROUND}

The CRR defines the prohibition on incentive to redeem in terms of the Additional Tier 1 capital in the broadest sense and it is present in the following elements:

- the provisions applying to instruments shall not contain any incentives for the institution to redeem the instruments;

- the provisions applying to instruments shall not explicitly or implicitly refer to an actual or possible call, redemption or repurchase of the instruments, except in the following cases:

a) the liquidation of the institution;

b) the discretionary repurchase of the instruments or other discretionary methods for the reduction of Additional Tier 1 capital, provided that the institution has obtained prior authorization from the competent authority in accordance with Article 77 of the CRR;

- the institution shall not indicate explicitly or implicitly that the competent authority would consent to a request for the call, redemption or repurchase of the instruments.

Similar condition apply to Tier 2 capital and eligible liabilities, however, there are some minor derogations.

In order to have standard detailed rules on incentive to redeem and standard practical application of such rules in the whole EU, Article 20 of Commission Delegated Regulation (EU) No 241/2014 of 7 January 2014 supplementing Regulation (EU) No 575/2013 of the European Parliament and of the Council with regard to regulatory technical standards for Own Funds requirements for institutions detailed the conditions set forth in the $\mathrm{CRR}^{4}$.

According to the Commission Regulation, each feature that leads to expectations regarding the probable repurchase of the capital instrument at the date of issue shall be considered as a repurchase incentive. Such cases may be the following:

a) A call option combined with an increase in the credit spread of the instrument if the call is not exercised.

The case above is the step-up, a classic example for repurchase incentive, when the issuer has the opportunity to repurchase the instrument after a fixed period (in general, after five years). However, if the issuer does not exercise this right, the credit spread added to the reference rate will gradually increase. As

4 https://eur-lex.europa.eu/legal-content/HU/TXT/?qid=1563526193750\&uri=CELEX:0201 4Ro241-20150707. 
a result, the yield of the instrument will also increase, making the instrument more expensive for the issuing institution (see: the case described in point 3). In the Commission Regulation, credit spread is translated into Hungarian as "hitelkockázati felár", which might be appropriate in certain contexts. At the same time, in this case, it is misleading, as it does not refer to the situation that the credit spread increases due to an increase in the issuer's credit risk, but rather to the fact that the increase in the interest rate spread is already fixed at the moment of issue, irrespective of changes in the issuer's credit quality (a similar problem arises in the case of point c), as well).

b) A call option combined with a requirement or an investor option to convert the instrument into a Common Equity Tier 1 instrument where the call is not exercised.

In this case, the issuer undertakes that after a specified period, if the issuer has not repurchased the instrument, the given bond shall be automatically converted to common equity or, at their own discretion, the investors shall be entitled to request the conversion of the bond to common equity (convertible bond). The aforementioned condition is considered to be a repurchase incentive, as owners of the institution are usually not interested in the conversion of the instrument to common equity. This move would decrease their ownership share in the institution, as well as their management and control powers. Consequently, the investors buying the instrument can be confident that the institution will repurchase the bond prior to its conversion into common equity.

c) A call option combined with a change in reference rate where the credit spread over the second reference rate is greater than the initial payment rate minus the swap rate.

In this case, after the specified period, the reference interest rate to which the yield of the instrument was linked changes (e.g. the yield payable in the first five years is $\mathrm{LIBOR}+2 \%$, while later BUBOR $+2.5 \%$ ). The laws do not ban the change of the reference interest rate, but the expected effect of the change on the yield of the instrument should be examined. The Basel Committee illustrates the situation above with the following example: at the date of issue, the original reference rate is $0.9 \%$, while the credit spread linked to the bond is $2 \%$ (as a result, the total yield paid for the first period is $2.9 \%$ ). The current value of the reference rate applicable in the second period is $1.2 \%$, therefore the credit spread promised for the second period cannot be higher than $1.7 \%$, otherwise the yield would increase. In this case, the realisation of the repurchase incentive can be examined only based on the reference yields at the date of issue, as there is no reliable data about how high the second reference yield will be in five years. 
d) A call option combined with an increase of the redemption amount in the future.

In this case, while the reference rate linked to the instrument and the credit spread remain unchanged, the amount for which the institution will be entitled to repurchase the instrument will be continuously increasing after a specific period of time. For example, if the institution undertakes to repurchase the instrument after a period of five years, it could not repurchase it for $100 \%$ of the price, but rather for $102 \%$ in the 6 th year, $104 \%$ in the 7 th year, etc. In this case, the yield of the instrument seems to be unchanged, but the costs of repurchase are continuously rising. The condition mentioned above can occur in particular in the case of undated instruments.

e) A remarketing option combined with an increase in the credit spread of the instrument or a change in reference rate where the credit spread over the second reference rate is greater than the initial payment rate minus the swap rate where the instrument is not remarketed.

The aforementioned case is essentially the same as the one mentioned in point c), with the difference that it is not linked to a call option, but the redistribution of the instrument instead.

f) A marketing of the instrument in a way which suggests to investors that the instrument will be called.

Even the CRR itself includes a condition according to which the provisions applying to instruments shall not explicitly or implicitly refer to the actual or possible call, redemption or repurchase of the instruments. For example, such a reference might be the following in the institution's prospectus: the institution plans to reinvest most of its profit into its own operation in the next five years, therefore the capital adequacy of the institution would become so strong that the institution would not need the Additional Tier 1 capital from the issued instrument, therefore it would probably repurchase it.

If the supervisory authority realises that either of the cases occurs as regards either the $\mathrm{AT}_{1}$, or the $\mathrm{T}_{2}$ equity instrument, it shall ban the issuing credit institution from taking into account the given instrument in its own funds. Credit institutions which are planning to issue such an instrument should consult the supervisory authority about whether the given bond fulfils all conditions set forth in the CRR already prior to the issue, because it is very difficult to amend the conditions afterwards.

It is important to mention another rule of the CRR, according to which CET1 equity instruments can be reduced, redeemed or repurchased, AT1 and T2 equity instruments and MREL-eligible liabilities can be called, redeemed, repaid or repurchased only if certain strict conditions are fulfilled and with the prior 
authorisation of the supervisory authority. In the light of the above, if an institution wants to repurchase a given instrument due to the rising cost of the fund, it cannot do so unless the circumstances fulfil the conditions or the supervisory authority does not provide its authorisation. Articles 77-78 of the CRR contain the rules of supervisory approval and the conditions of the possible reduction of own funds.

The draft of the Commission Regulation on the detailed rules of incentive to redeem was elaborated by the EBA. During the consultation about the draft of the Commission Regulation, market participants indicated that it could be practical to authorise the EBA to establish further cases of repurchase incentive or indicate in the RTS if the list is not extensive. In its response to the aforementioned question, the EBA pointed out that it did not want to receive such authorisation and, according to its current knowledge of the market, the list was extensive (EBA, 2013). Interestingly, it contradicts to the position of the Basel Committee, which also provided a list of the cases of repurchase incentive. At the same time, the latter body clearly emphasised that the list they provided was not extensive and repurchase incentive could have other forms, as well (BCBS, 2017). In the same document, the Basel Committee also established that the fact itself according to which an instrument will have variable interest rates instead of fixed interest rates after a certain period, while the risk premium compared to the reference interest rate remains unchanged, does not necessarily mean that the fact of repurchase incentive exists. However, supervisory authorities should examine such cases with particular care.

Another important criticism of the draft of the Commission Regulation stated that the definition of repurchase incentive components was too general, leaving supervisory authorities scope for interpreting them according to their own viewpoint, thus creating considerable uncertainty in the market. In the course of creating the draft of the regulation, the EBA ignored this opinion, as well, since the supervisory authorities concerned always have the above-mentioned scope of powers.

\section{PRACTICAL EXAMPLES}

It is not always easy to decide whether, in relation to a specific capital item repurchase incentive occurs or not. In the examples below, we demonstrate how the competent authorities evaluated individual cases. 
a) In its Answer No. 2016_29885, the EBA examined a case in which a bank issued a hybrid equity item that had a fixed-interest rate in the first period, and then had a floating rate coupon after the first period. After the first period, the issuer had the opportunity to redeem the instrument. In the case of both the fixed and the variable interest rate, the interest rate spread applied remained unchanged. At the same time, one of the conditions prescribed that the variable interest rate could not be lower than the fixed interest rate. In its overall evaluation of the conditions above, the EBA established that the given instrument included repurchase incentive, because the interest paid in the second period is the same or will be higher that the fixed interest paid in the first period.

b) In its Answer No. 2016_2848 ${ }^{6}$, the EBA examined the case when an institution issued a new instrument with exactly the same conditions as the ones of a previously issued equity instrument (tap issuance). The question was whether it was a case of incentive to redeem if the credit spread applied when issuing the new instrument was lower than the spread applied at the time of issue of the original instrument. The question was raised because the original interest rate and the new interest rate condition applied after the first period in the case of the newly issued instrument will be the same. However, due to the lower credit spread, the case of the second issue, the difference between the interest rates used at the time of issue and after the change of the interest rate will be greater. First, in its Answer, the EBA pointed out that when applying the CRR, all similar cases of tap issuance should be considered a new issuance, therefore the question can be raised only when, in the case of the original issue, the interest rate is changed and the repurchase right is granted after more than five year. Even in the case of tap issuance, the first call date has to be a minimum five years after the date of the tap. If, in the event of tap issuance, all other conditions agree, but the risk premium is lower, owing to the resulting higher interest spread, the tap issuance contains an incentive to redeem element, therefore the instrument cannot be taken into account in the own funds.

c) In its Answers in connection with the interpretation of Basel III, the Basel Committee examined the question how it should be judged when, following the first call option, the bank takes over the amount of the withholding tax to be paid by the bond owners on the interest received (i.e. the yield paid on the bond increases, however, the interest rate included in the conditions of the bond remains unchanged). In the view of the Committee, it should also be considered as

5 https://eba.europa.eu/single-rule-book-qa/-/qna/view/publicId/2016_2988.

6 https://eba.europa.eu/single-rule-book-qa/-/qna/view/publicId/2016_2848. 
step-up, i.e. a repurchase incentive, therefore, such a bond cannot be considered as Additional Tier 1 capital (BCBS, 2017).

d) The Answers of the Basel Committee to the questions related to repurchase also include the following: if a bank intends to repurchase one of its instruments issued earlier and replace it by a new instrument that has higher credit spread, the supervisory authority shall not approve of the repurchase. Namely, it will raise market expectations based on which the bank will repurchase all other instruments of lower yields soon (BCBS, 2017).

e) The Basel Committee also expressed that the fact itself that an instrument allows the institution to repurchase the instrument several times following the initial five-year period does not involve incentive to redeem. In the light of the above, if it does not contain any other incentive to redeem component, it can be taken into account in the own funds (BCBS, 2017).

\section{AT1 TEMPLATE}

In order to standardise and make comparable the issuances of Additional Tier 1 capital instruments in the European Union and make sure that they contain all conditions allowing the instrument to be taken into account in the own funds, in October 2016, the EBA published a document that provided a model-contract template for such issuances (EBA, 2016).

This template includes several provisions of the CRR on prohibiting incentive to redeem. Based on the EBA's experience, if an institution intends to exercise its right of repurchase within five years after the issue of the instrument, it will repurchase the entire portfolio of the given equity instrument. The contract template contains this provision, but as it is not forbidden by the law, the EBA mentions as a possible condition that the institution shall repurchase only a part of the portfolio of the given instrument.

The contract template refers to Articles 77-78 of the CRR to make it clear for investors that, in spite of the fact that the conditions of the bond allow the issuer to repurchase the instrument, it can only be repurchased if the conditions mentioned in Article 78 are fulfilled (the institution shall replace the instrument by capital of at least the same good quality or it is able to meet prudential requirements even after the repurchase of the given instrument) and the supervisory authority has approved of the repurchase. 


\section{CONCLUSION}

The CRR lays down several conditions of regarding taking into account an instrument in the own funds. The numerous conditions in the CRR include a prohibition on incentive to redeem, whose judgement is controversial in many cases. Although the laws list the possible cases of incentive to redeem, the evaluation of certain special cases may require interpretation by the supervisory authority. Based on the above, market participants should be familiar with the relevant legislation and interpretation of the law, because even a seemingly completely appropriate instrument may fail during a detailed regulatory investigation if the condition of prohibiting incentive to redeem is not fulfilled.

\section{REFERENCES}

BCBS (2010): Basel III: A global regulatory framework for more resilient banks and banking systems. Basel Committee on Banking Supervision, December 2010, https://www.bis.org/publ/bcbs189. pdf.

BCBS (2017): Basel III definition of capital - Frequently asked questions. Basel Committee on Banking Supervision, September 2017, https://www.bis.org/bcbs/publ/d417.pdf.

EBA (2013): EBA FINAL draft Regulatory Technical Standards on own funds (Part 1) under Regulation (EU) No 575/2013 (Capital Requirements Regulation - CRR). EBA/RTS/2013/o1, 26 July 2013, https:/eba.europa.eu/documents/10180/359901/EBA-RTS-2013-01-draft-RTS-on-Own-FundsPart-1.pdf/d1217588-ffo5-4063-8d6f-5d7c81f2cc64.

EBA (2016): EBA standardised templates for Additional Tier 1 (AT1) instruments - Final. 10 October 2016, https://eba.europa.eu/documents/1018o/1360107/Final+AT1+standard+templates+.pdf.

EBA (2018): EBA Report on the Monitoring of Additional Tier 1 (AT1) Instruments of European Union (EU) Institutions - Third Update. 28 May 2018, https:/eba.europa.eu/documents/10180/2087449/ AT1+report+Q2+2018+update.pdf.

EBA (2019): EBA Report on Funding Plans. August 2019, https:/eba.europa.eu/documents/10180/2908903/EBA+2019+Report+on+Funding+Plans.pdf.

Corcuera, J. M. -Fajardo, J. -Schoutens, W. -Valdivia, A. 2014: CoCos with Extension Risk: A Structural Approach. 21 December 2014, https://papers.ssrn.com/sol3/papers.cfm?abstract_ id $=2540625$. 